108

Received: July 8, 2009

Accepted: November 15, 2009
Macedonian Journal of Animal Science, Vol. 2, No. 2, pp. 235- 240 (2012)

In print ISSN $1857-6907$

On line ISSN $1857-7709$

UDC: $636.2 .09: 616.5-002]: 311.21(496.528)$

Short communication

\title{
IMPACT OF THE MANAGEMENT SYSTEM ON THE PRESENCE OF HYPERDERMOSIS IN CATTLE
}

\author{
Pellumb Zalla, Natalia Shoshi, Bejo Bizhga, Rezart Postoli, Dhimiter Rapti \\ Faculty of Veterinary Medicine, Agriculture University of Tirana, Albania \\ p_zalla@yahoo.com
}

\begin{abstract}
A study on impact of the age and the type of breeding on the infection level of cattle hyperdemosis was conducted in the cattle of Kruja district through the use of clinical control of the livestock. Out of 386 cattle controlled 42 individuals proved to be positive, or $10.88 \%$ out of the total. The highest percentage of infection was present in the age groups between 2 and 5 years old at $14.2 \%$ of cattle, while the lowest percentage of infection was detected in cattle with the age group at 8 years old or with $2.63 \%$ of cattle. This was statistically tested where $\mathrm{R}^{2}=0.9228$. The highest percentage of infection was in cattle that are being bred in a pasture regime at $5.79 \%$, while the infection percentage in the livestock bred in the pen-pasture regime was at $14.19 \%$. the lowest percentage was in cattle that are being bred in the pen regime at $5.91 \%$. The larvae accumulated from the infected cattle were identified as larvae of bovis hypodermosis.
\end{abstract}

Key words: cattle; Hypoderma bovis; management system; infection rate

\section{ВЛИЈАНИЕ НА РЕЖИМОТ НА ОДГЛЕДУВАЊЕ ВРЗ ПРИСУСТВОТО НА ХИПЕРДЕРМОЗА КАЈ ГОВЕДАТА}

\begin{abstract}
Реализирано е истражување за одредување на влијанието на возраста, начинот на одгледување и нивото на инфекција со говедската хипердермоза кај говедата, во областа Круја преку примена на клиничка контрола на животните. Од 386 говеда се контролирани 42 индивидуи кои се покажале позитивни, односно 10,88\% од вкупниот број. Највисок процент на инфекција е присутен кај групите на возраст помеѓу 2 и 5 години $(14,2 \%)$, додека најнизок процент на инфекција е детектиран кај говедата од возрасната група од 8 години $(2,63 \%)$. Ова е статистички тестирано каде што $\mathrm{R}^{2}=0.9228$. Највисок процент на инфекција имаше кај говедата кои се одгледувани со режим на напасување $(5,79 \%)$, додека процентот на инфекција кај домашните животни кои се одгледувани на комбиниран режим (пашеа+затворено) е 14,19\%, а најнизок процент е кај говедата кои се одгледувани во затворено (5,91\%). Ларвите собрани од инфицираните говеда се идентификувани како ларви од Bovis hypodermosis.
\end{abstract}

Клучни зборови: говеда; Hypoderma bovis; систем; на менаџмент процент на инфекција

\section{INTRODUCTION}

Hypodermosis is a myiases induced by larvae forms of the dipters pertaining to the family Oestridae: Hypoderma bovis Deger (1776) and Hypoderma lineatum De Villers (1789).

As such, that is a disease of a chronic nature which is characterized by the presence of parasite nodules under the skin at the lumbo-dorsalis region of the infested animals. Hypodermosis is a disease that is widespread in Albania (Tagari, 1969; Zalla, 2004) as well as in many other countries of the Northern Hemisphere. Hypodermosis in cattle is a kind of disease whose advance as such is heavily dependent on the climate conditions and the type of breeding in use. The climate changes along with the social and economic changes that occurred in Albania right after the ' 90 s which needless to say were accompanied by changes in the manner of breeding cattle, as well as the lack of prevention 
programs of hypodermosis have all played a conspicuous part in the spread of disease in Albania. The purpose of the study is to evaluate the impact of the management system in cattle at the level of infestation from the hypodermosis.

\section{MATERIAL AND METHODS}

The age and the type of breeding are considered to be among the key factors that influence the type of infestation of cattle from Hypodermosis. The study was conducted in several areas of the Durres district. The animals were randomly selected based on the epidemiological formula (386 heads). They were grouped based on their age (0-2 years old 66 cattle, 2-5 years old 113 cattle, 5-8 years old 128 cattle, and over 8 years of age 76 cattle) and the type of breeding (pen-kept 86 cattle, pen and pasture kept 161 cattle, pasture 39 cattle). The animals were subjected to a clinical control by eye for the presence of the parasite foruncula in the period from February to July 2008. The test was repeated almost every month. For each animal checked notes were taken down with regard to: no. matriculation, climate area, age, breed, date of check, type of breeding, treatments with antiparasite concoctions. The accumulated larvae from each animal were preserved in alcohol $70^{\circ}$ and subsequently identified by using the morphological keys as described by James (1947) and Zumpt (1965).

\section{RESULTS}

From the clinical control over the presence of nodules of hypodermosis it turned out that the infestation level of cattle from hypodermosis was at $10.88 \%$. The prevalence value of hypodermosis according to the age-groups was: a) age-group 0-2 years of age $13.63 \%$; b) age-group 2-5 years of age $14.15 \%$, age-group 5-8 years of age $10.15 \%$; c) age-group over 8 years of age $2.63 \%$ (Tab 1 , Fig. 1).

Table 1

Prevalence value of Hypodermosis of cattle based on age-groups

\begin{tabular}{|c|c|c|c|c|c|c|c|c|c|c|c|c|c|}
\hline \multirow[t]{4}{*}{ Village } & \multirow{4}{*}{ 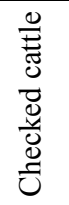 } & \multicolumn{12}{|c|}{ Age (years) } \\
\hline & & \multicolumn{3}{|c|}{$0-2$} & \multicolumn{3}{|c|}{$2-5$} & \multicolumn{3}{|c|}{$5-8$} & \multicolumn{3}{|c|}{ Over 8} \\
\hline & & \multirow[t]{2}{*}{ Nr. } & \multicolumn{2}{|c|}{ Positive } & \multirow[t]{2}{*}{$\mathrm{Nr}$. } & \multicolumn{2}{|c|}{ Positive } & \multirow[t]{2}{*}{$\mathrm{Nr}$. } & \multicolumn{2}{|c|}{ Positive } & \multirow[t]{2}{*}{$\mathrm{Nr}$. } & \multicolumn{2}{|c|}{ Positive } \\
\hline & & & Nr. & $\%$ & & Nr. & $\%$ & & $\mathrm{Nr}$. & $\%$ & & $\mathrm{Nr}$. & $\%$ \\
\hline Fushë - Krujë & 92 & 16 & 2 & 12.5 & 26 & 3 & 11.53 & 29 & 2 & 6.89 & 21 & 0 & 0 \\
\hline Larushk & 92 & 16 & 1 & 6.25 & 25 & 2 & 8 & 32 & 2 & 6.25 & 19 & 1 & 5.26 \\
\hline Vrion & 71 & 11 & 2 & 18.18 & 22 & 5 & 22.72 & 23 & 3 & 13.04 & 15 & 1 & 6.66 \\
\hline Bubq & 86 & 14 & 3 & 21.42 & 27 & 4 & 14.81 & 29 & 4 & 13.79 & 13 & 0 & 0 \\
\hline Abaze & 45 & 9 & 1 & 11.11 & 13 & 2 & 15.38 & 15 & 2 & 13.3 & 8 & 0 & 0 \\
\hline Total & 386 & 66 & 9 & 13.63 & 113 & 16 & 14.15 & 128 & 13 & 10.15 & 76 & 2 & 2.63 \\
\hline
\end{tabular}

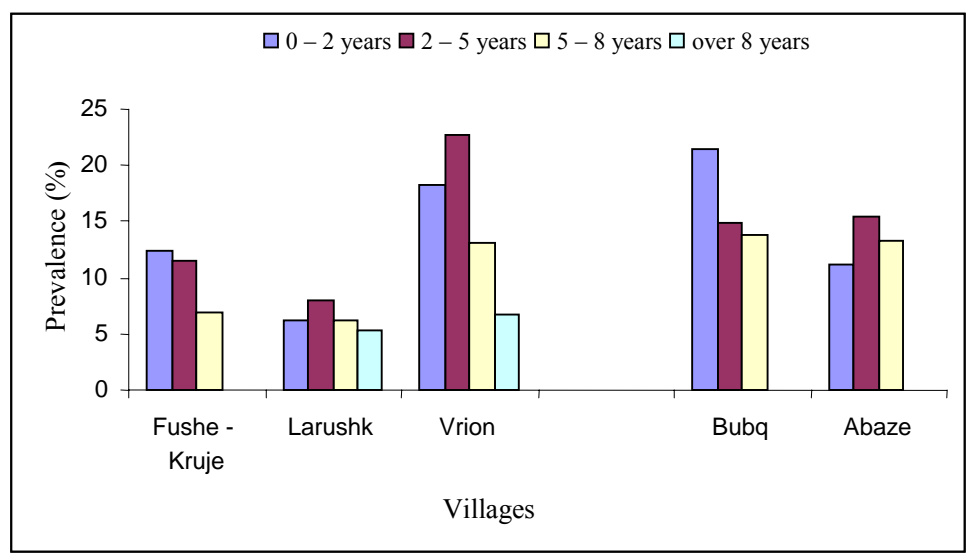

Fig. 1. Compared values of hypodermosis prevalence of cattle based on age-groups 
All of the larvae accumulated from the controlled animals were identified as larvae of hyperdema bovis.

The correlation between the age-group and the infestation levelis expressed through the linear regress equation $\left(\mathrm{R}^{2}=0.9228\right)$, where the regress line indicates the level of reduction in infestation from hypodermosis with the increase of age (Fig. 2).

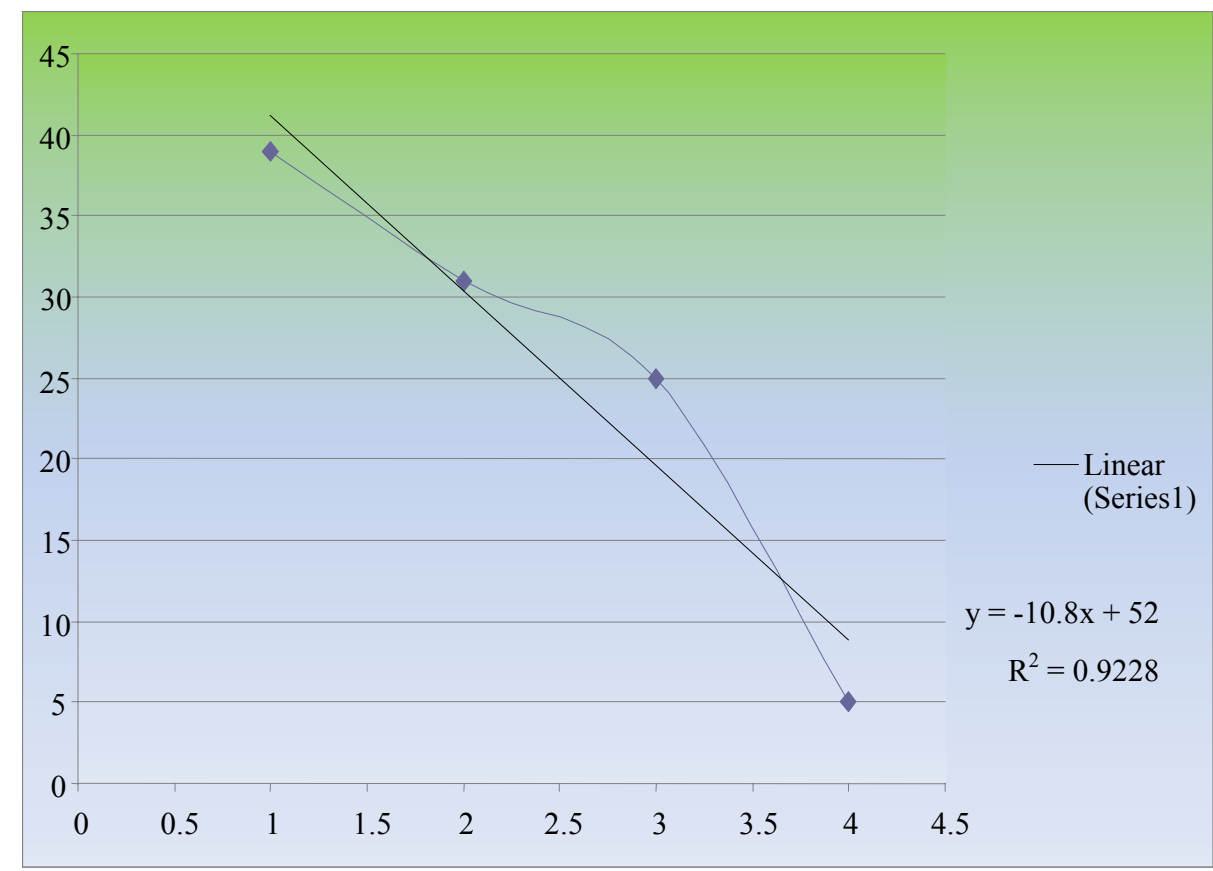

Fig. 2. Statistical analysis of the correlation between the age and the infestation level

From the clinical control of animals under the focus of this study divided on the type of breeding it turned out that the disease prevalence was: a) shed/pen regime $5.91 \%$; b) pen - pasture regime $14.19 \%$; c) pasture regime $15.79 \%$ (Tab. 2; Figs. $3,4)$.

Table 2

Hypodermosis prevalence depending on the type of breeding

\begin{tabular}{|c|c|c|c|c|c|}
\hline \multirow{2}{*}{ Village } & \multirow{2}{*}{ Area } & \multirow{2}{*}{ Menagement system } & \multirow{2}{*}{ Checked cattle } & \multicolumn{2}{|c|}{ Positive } \\
\hline & & & & Nr. & $\%$ \\
\hline \multirow{3}{*}{ Fushe- Kruje } & \multirow{3}{*}{ Field } & Pen regime & 80 & 5 & 6,25 \\
\hline & & Pen-pasture regime & 12 & 2 & 16,66 \\
\hline & & pasture & 0 & 0 & 0 \\
\hline \multirow{3}{*}{ Larushk } & \multirow{3}{*}{ Field } & Pen regime & 86 & 5 & 5,81 \\
\hline & & Pen-pen regime & 6 & 1 & 16,66 \\
\hline & & Pen & 0 & 0 & 0 \\
\hline \multirow{3}{*}{ Vrion } & \multirow{3}{*}{ Hills } & Pen regime & 7 & 0 & 0 \\
\hline & & Pen-pasture regime & 54 & 9 & 16,66 \\
\hline & & Pasture & 10 & 2 & 20 \\
\hline \multirow{3}{*}{ Bubq } & \multirow{3}{*}{ Hills } & Pen regime & 13 & 1 & 7,69 \\
\hline & & Pen-pasture regime & 58 & 8 & 13,79 \\
\hline & & Pasture & 15 & 2 & 13,33 \\
\hline \multirow{3}{*}{ Abaze } & \multirow{3}{*}{ Mountain } & Pen regime & 0 & 0 & 0 \\
\hline & & Pen-pasture regime & 31 & 3 & 9,67 \\
\hline & & Pasture & 14 & 2 & 14,28 \\
\hline
\end{tabular}




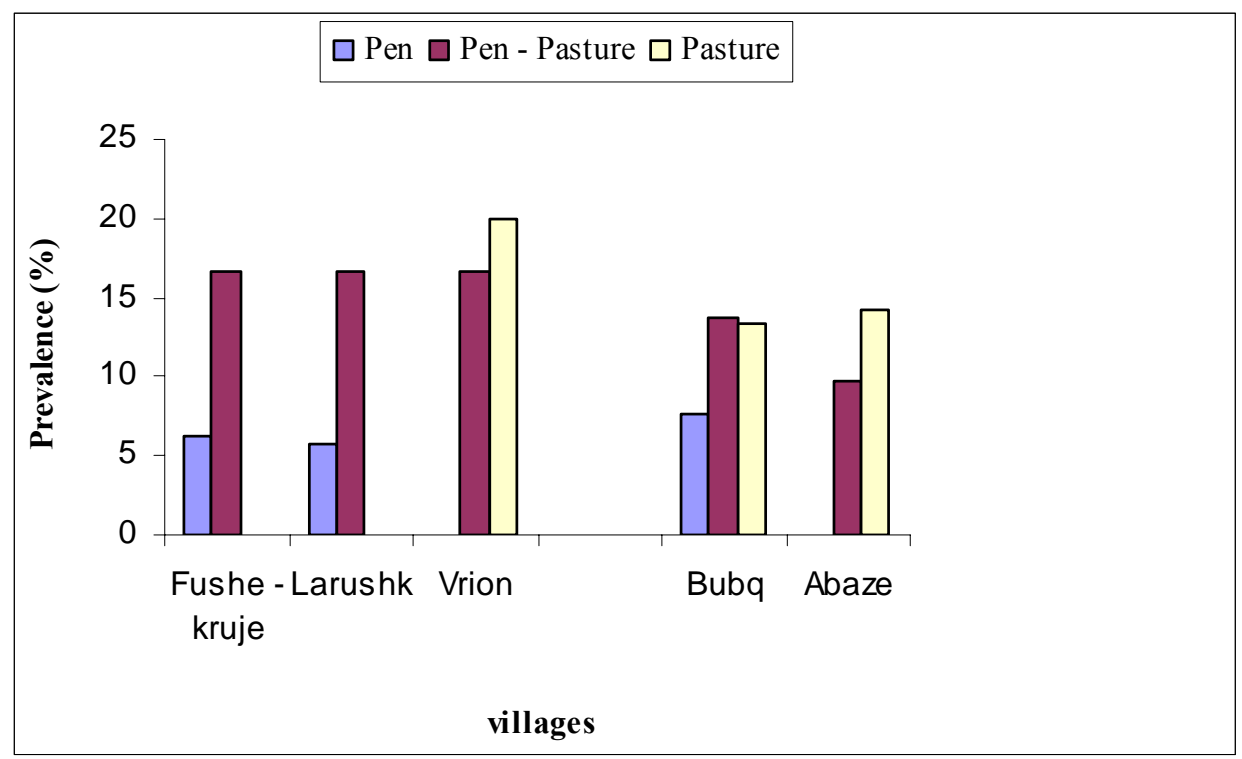

Fig. 3. The prevalence value of hypodermosis based on the type of breeding in villages under the focus of study.

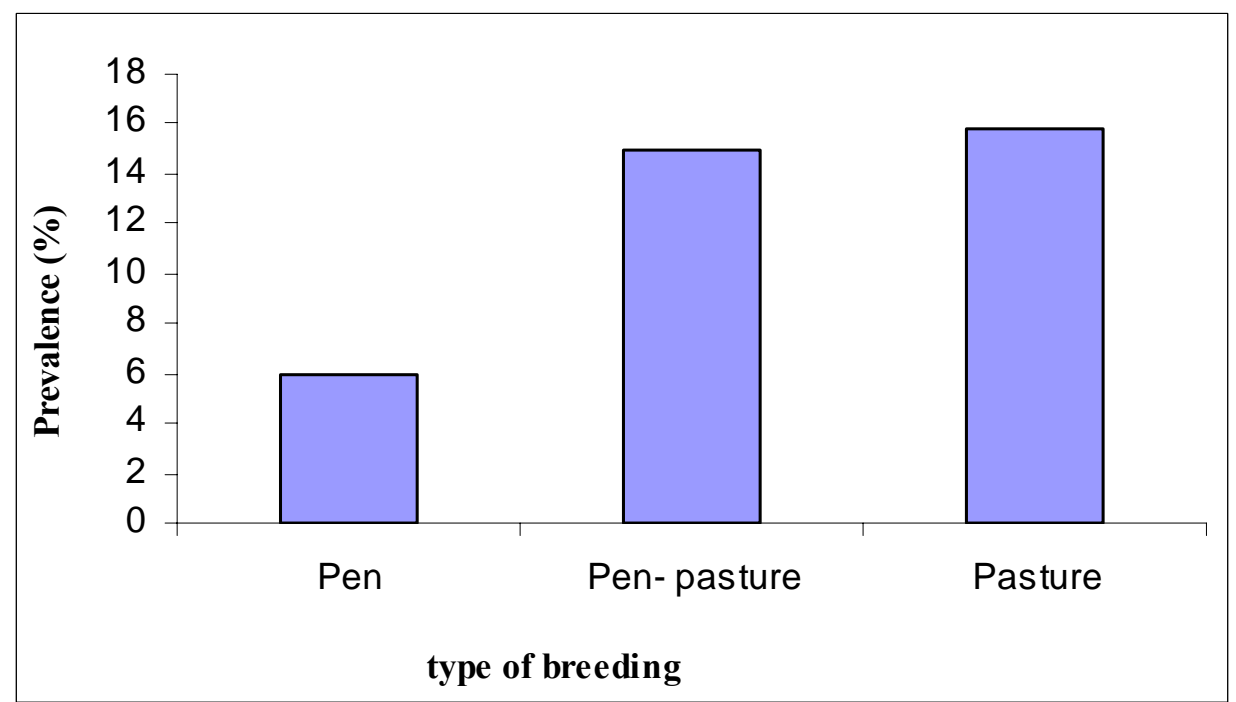

Fig. 4. Compared prevalence values based on type of breeding.

\section{DISCUSSION}

The findings of this study point to the presence of the hypodermosis in cattle in high values in the Durres district. The disease as such is prevalent in young age-groups if compared to the adult age-groups. In animals that are infested for the first time there is an absence of the inflammatory reaction in the spot where the larvae penetrate. The level of circulation of the eosinofiles is at insignificant levels (Nelson \& Weintraub, 1972; Nelson, 1987).

In the re-infested animals with hypodermosis one can easily see inflation in the place where there is a penetration of the larvae and an accumulation of the eozionfiles and neutrofiles about the larvae (Nelson \& Weintraub, 1972).

The lack of inflammation after the first infestation is explained by several anti-inflammatory activities of the hypodermosis A and hypodermosis $\mathrm{B}$ respectively. This absence of reaction after the first infestation indicates that the immuno-cell system involved in the immuno-depression (Baron, 1990; Boulard, 1992). The development of the invasive larvae of the hypoderma spp.in the uninfested animals is 10 times higher than in heavily re-infested cattle (Estfjev, 1980; Minar \& Breev, 1983). 
As to the above, we might safely state that the immunitary reaction in young animals is at levels that stand lower than in animals of an average or advanced age.

That is, the young animals are much more pre-disposed to be infested by hypoderma than when compared with other categories of animals. The tissues of young animals are tender and do not constitute a hurdle for the migration of larvae L1. In the adult animals the tissues are compacted and the binding tissue is mature, its hide is skin, the glands with an internal secretion are entirely developed and produce a great many hormones etc. All of these factors constitute what we term as the immunity of age.

As a conclusion, it is safe to point out that the resistance against the infestations from the hypoderma is gained after repeated exposures of the animals against the parasite.

Our results are actually in keeping with the data of other researchers in connection to the influence of age at the level of infestation from hypodermosis (Gingrich, 1980; Baron \& Weintraub, 1987; Martinez-Moreno, 1992).

In Albania after the '90s the state-owned farms, in which animals were mainly kept in a pen regime were destroyed and the animals were given away to the farmers. The farmers breed a limited number of cattle (1-5 cattle). They mostly keep them in a pen-pasture regime or in other instances even in pasture regimes.

The low values of the prevalence of hypodermosis in the animals in pen regime when compared to animals bred in a pasture and pen-pasture regimes trace the origin in the biology of the parasite. The development of the free life stage of pupa and imago depends not only on the climate-land changes, but also on the breeding conditions. The larvae that fall off from the animals to the surrounding pen ground do not find fitting conditions (temperature, moisture and lighting) to be transformed into pupes. The adult insects, particularly those of the hypoderma bovis do not enter into the pen grounds, so we are going to end up with less eggs placed on the hide and consequently fewer larvae that will penetrate the hides.

The larvae of the cattle hypoderms that are being kept in a pen-pasture environment at a certain point (which is chiefly determined by the temperature of the environment) will abandon the cattle/cow and will fall off to the ground, in which case the conditions for their conversion into pupa and later into imagos are much better than in the pens. Thus the infestation level of these cattle will be much higher than in those that are bred in the pen regimes.

Needless to say, these types of data are in line with those of the existing literature, in which case the high level of infestation from the hypodermosis has been observed in animals that are bred in the pen regime (Puccini et al., 1992; Papadopoolos et al., 1996; Otranto et al., 2001; Boulard et al., 1996).

The larvae of the third stage were identified as larvae of the hypoderma bovis. These data contradict the data as recorded in the neighboring countries of Albania with the same geographical latitude, in which the larvae of hypoderma lineatum have been observed and identified. Hypoderma bovis is considered as a serious pest to the cattle in the Northen Hemisphere and the impact on the health of animals is a lot more important than that of hypoderma lineatum, because in the case when the treatment is not done at the first stage of the larvae strokes/paralysis might occur.

\section{CONCLUSIONS}

The findings of this study showed that the presence of hypodermosis in the cattle of the Durres district is at $10.88 \%$ cattle which have been the focus of the study. With the advancing of age the infestation level in animals goes down from hypodermosis, $13.63 \%$ in the age-groups $0-2$ against $2.63 \%$ in the age-groups over 8 years of age.

The lowest level of infestation from hypodermosis is in animals which are fed in the pen regime when compared to the other forms of animal breeding.

The study indicated that hypodermosis in cattle in the field areas is triggered mainly from the larvae forms of hypoderma bovis.

We think that it is necessary to conduct early prophylactic training against hypodermosis, which significantly reduces the infestation intensity from the parasites and avoids the risk of spreading it to other regions across the country.

\section{REFERENCES}

[1] Boulard C., Villejoubert C., Moire N., Losson B., Lonneux J. F. (1996): Sero-surveillance of hypodermosis in a herd under Therapeutic control. Effect of low level of infestation. Vet. Parasitol. 66 (1-2): 109-117. 
[2] Baron R. W. (1990): Cleavage of purified bovine complement component C3 in larval Hypoderma lineatum (Diptera : Oestridae) hypodermins. Journal of Medical Entomology, 27, 899-904.

[3] Baron R. W., Weintraub J. (1987b): Immunological responses to parasitic arthropods. Parasitology Today, 3, $77-82$.

[4] Chabaudie N., Villejoubert C., Boulard C. (1991): The response of cattle vaccinated with hypodermin A to a natural infestation of Hypoderma bovis and Hypoderma lineatum. Int. J. Parasitol. 1991 Nov; 21 (7):859-62.

[5] Evstafjev M. N. (1980): Role of immunity during Hypoderma tosis of cattle. Parasitologia, 14 (3), 197-205.

[6] Gingrich R. E. (1982): Acquired resistance to hypoderma lineatum: comparative immune response of resistant and susceptible cattle. Vet. Parasitol., 9 , 233-242.

[7] Nelson W. A., Weintraub J. (1972): Hypoderma lineatum (De Vill) (diptera: Oestridae): invasion of the bovine skin by newly hatched larvae. Journal of Parasitology, 58, 614-624.

[8] Martínez-Moreno F. J. (1992): Estudio inmunológico de la hipodermosis bovina. Doctoral Thesis. Córdoba. Spain.

[9] Minar, J. (1987): Studies on population ecology of cattle warble flies as a model of the internal regulatory system in parasite and host populations. In: Warble-fly Control in Europe. IV. V. Puccini \& Tassi eds., Universita degli Studi di Bari, pp. 51-200.
[10] Minar J., Breev K. A. (1982): Laboratory and field rearing of the warble fly Hypoderma bovis (De Geer) (Diptera, Hypodermatidae) in the research of its population ecology. Folia Parasitologica (Praha), 29, 351-360.

[11] Otranto D., Testini G., Sottili R., Capelli G., Puccini V. (2001): Screening of commercial milk samples using ELISA for immuni-epidemiological evidence of infection by the cattle grub (Diptera: Oestridae). Vet. Parasitol. 99, 241-248.

[12] Puccini V., Giangaspero A., Fasanella A. (1992): Incidence of bovine hypodermosis in Apulia region (Italy). pp. 9-20. In: Improvements in the Control Methods for Warble-fly in Cattle and Goats, Gasca A., S. Hernandez, J. Martinez and K. Pithan (Eds). Cordoba, Spain, May 810, 1991. COST 811. Commission of the European Communities, Brussels.

[13] Papadopoulos E., Himonas C., Boulard C. (1996): The prevalence of bovine hypodermosis in Greece. pp. 19-24. In: Improvement of means of Control of Warble-fly in Cattle and Goats. Proc. XIII European COST 811. Parma, Italy, Sept. 5-6, 1996.

[14] Zalla P., Otranto D., Testini G., Zanaj S. (2005): Cattle grub infestation by Hypoderma sp. In: Albania and risks for European countries. Vet. Parasitology, 128, 157-162.

[15] Tagari V. (1969): Disa te dhena mbi hipodermozen e gjedhit ne Shqiperi. Bul. and Shk. Bujq. Nr. 2. 